\title{
PROSES BERPIKIR KRITIS SISWA DALAM MEMECAHKAN MASALAH MATEMATIKA REALISTIK MATERI GEOMETRI DITINJAU DARI GAYA BELAJAR
}

\author{
Finsensius Yesekiel Naja ${ }^{1}$, Agustina $\mathrm{Mei}^{2}$, Sofia $\mathrm{Sa}^{3}{ }^{3}$ \\ ${ }^{1}$ Universitas Flores, Jln. Sam Ratulangi, Ende-Flores-NTT \\ ${ }^{2}$ Universitas Flores, Jln. Sam Ratulangi, Ende-Flores-NTT \\ ${ }^{3}$ Universitas Flores, Jln. Sam Ratulangi, Ende-Flores-NTT \\ Email: meiagustina612@gmail.com
}

\begin{abstract}
The purpose of this study is to describe the profile of students' critical thinking in solving realistic mathematical problems of geometry material in terms of learning styles. This research is a descriptive study with a qualitative approach. Critical thinking in this study refers to critical thinking with FRISCO criteria. In this study, subjects were taken from students of class VII SMP N 2 Ende Selatan. Each student's research subjects have visual, auditory and kinesthetic learning styles. Data collection is done by providing a Problem Solving Test (TPM) and an interview. The results obtained, subjects who have a visual learning style, critical thinking processes in solving realistic mathematical problems, able to understand problems, the subject has not been able to determine ways to solve problems, the subject has not been able to carry out the settlement and the subject does not re-examine. Subjects who have auditory learning styles, critical thinking profiles in solving realistic mathematical problems are able to understand problems, but the subject does not re-examine. Subjects who have kinesthetic learning styles of critical thinking processes in solving realistic mathematical problems, are able to understand problems, are able to plan problems, subjects can carry out well and check the results.
\end{abstract}

Keywords: realistic mathematics; geometry; learning style.

\begin{abstract}
Abstrak
Tujuan penelitian ini adalah mendeskripsikan profil berpikir kritis siswa dalam memecahkan masalah matematika realistik materi geometri ditinjau dari gaya belajar. Penelitian ini termasuk penelitian deskriptif dengan pendekatan kualitatif. Berpikir kritis pada penelitian ini mengacu pada berpikir kritis dengan kriteria FRISCO. Pada penelitian ini, subjek diambil dari siswa kelas VII SMP N 2 Ende Selatan. Subjek penelitian siswa masing-masing memiliki gaya belajar visual, auditory dan kinesthetik. Pengumpulan data dilakukan dengan cara pemberian Tes Pemecahan Masalah (TPM) dan wawancara. Hasil peneltian yang diperoleh, subjek yang memiliki gaya belajar visual, proses berpikir kritisnya dalam memecahkan masalah matematika realistik, mampu memahami masalah, subjek belum mampu menentukan cara untuk memecahkan masalah, subjek belum mampu melaksanakan penyelesaian dan subjek tidak memeriksa kembali. Subjek yang memiliki gaya belajar auditory, profil berpikir kritisnya dalam memecahkan masalah matematika realistik mampu memahami masalah, mampu melaksanakan dengan baik, namun subjek tidak memeriksa kembali. Subjek yang memiliki gaya belajar kinestetik proses berpikir kritisnya dalam memecahkan masalah matematika realistik, mampu memahami masalah,mampu merencanakan masalah,subjek dapat melaksanakn dengan baik serta memeriksa kembali.
\end{abstract}

Kata kunci: matematika realistik; geometri; gaya belajar 
Proses Berpikir Kritis Siswa Dalam Memecahkan Masalah Matematika Realistik Materi Geometri Ditinjau Dari Gaya Belajar

Fisensius Yesekiel Naja ${ }^{1}$, Agustina $\mathrm{Mei}^{2}$, Sofia $\mathrm{Sa}^{3}{ }^{3}$

JUPIKA: Jurnal Pendidikan Matematika, Volume 3. Nomor. 2. September 2020. Hal.51-60

\section{PENDAHULUAN}

Belajar matematika berkaitan erat dengan aktivitas dan proses belajar serta berpikir, karena karakteristik matematika merupakan suatu ilmu dan human activity, yaitu bahwa matematika adalah pola berpikir, pola mengorganisasikan pembuktian yang logis, yang menggunakan istilah yang didefinisikan dengan cermat, jelas, dan akurat, Sabandar (2008). Johnson (2007) menyatakan bahwa seseorang yang berpikir kritis akan mengevaluasi pemikiran tersirat dari apa yang ia dengar dan baca, dan ia meneliti proses berpikirnya sendiri ketika memecahkan masalah, membuat keputusan atau mengembangkan sebuah rencana baru. Pemikir kritis tidak mudah menerima begitu saja cara mengerjakan sesuatu, dan ia tidak mudah menerima kebenaran suatu pernyataan hanya karena orang lain membenarkannya, namun ia akan mencari alasan logis atas kebenaran pernyataan tersebut.

Gokhale (2015) menyatakan bahwa dengan pembelajaran yang dilakukan secara kelompok dapat memberikan kesempatan kepada peserta didik untuk berdiskusi dan bertanggung jawab terhadap pembelajaran mereka dan mendorong peserta didik menjadi pemikir kritis yang baik. Berpikir kritis dapat diinterpretasikan dalam berbagai cara. Salah satu berpikir tingkat tinggi adalah berpikir kritis. Ada beberapa alasan mengapa siswa dituntut agar terbiasa dalam melakukan berpikir kritis, adalah untuk memenuhi 1) mencari dan menerapkan informasi dari lingkungan sekitar dan sumber-sumber lain secara logis, kritis, kreatif, dan inovatif, 2) menunjukkan kemampuan berpikir logis, kritis, kreatif, dan inovatif, 3) menunjukkan kemampuan belajar secara mandiri sesuai dengan potensi yang dimilikinya, 4) menunjukkan kemampuan menganalisis dan memecahkan masalah dalam kehidupan sehari-hari, 5) menguasai pengetahuan yang diperlukan untuk mengikuti pendidikan tinggi.

Banyak definisi berpikir yang telah diungkapkan oleh para ahli. Solso (2008) mendefinisikan berpikir sebagai proses menghasilkan representasi mental yang baru melalui transformasi informasi yang melibatkan interaksi secara kompleks atribut-atribut mental yang mencakup penilaian, abstraksi, penalaran, imajinasi dan pemecahan masalah. Sedangkan Siswono (2008) menyatakan berpikir sebagai suatu kegiatan mental yang dialami seseorang bila mereka dihadapkan pada suatu masalah atau situasi yang harus dipecahkan. Dengan demikian penulis menyimpulkan bahwa berpikir merupakan proses yang melibatkan operasi mental yang dilakukan seseorang ketika dia dihadapkan pada suatu masalah atau situasi yang harus dipecahkan.

Tujuan dari berpikir kritis adalah untuk mencapai pemahaman yang mendalam Johnson (2007). Dengan pemahaman yang mendalam tersebut seseorang akan mampu mengungkap makna di balik informasi yang diperoleh sehingga dapat menemukan kebenaran di tengah banyaknya informasi dan mampu membuat keputusan yang tepat dalam segala tindakan.

Terkait dengan berpikir kritis, Ennis (1995) mendefinisikan enam kriteria berpikir kritis yang disingkat dengan FRISCO (Focus, Reason, Inference, Situation, Clarity, Overview) sebagai berikut: 
Proses Berpikir Kritis Siswa dalam memecahkan Masalah Matematika Realistik Materi Geometri Ditinjau Dari Gaya Belajar Fisensius Yesekiel Naja ${ }^{1}$, Agustina $\mathrm{Mei}^{2}$, Sofia $\mathrm{Sa}^{\prime}{ }^{3}$

Jupika: Jurnal Pendidikan Matematika, Volume 3. Nomor 2. September 2020. Hal.51-60

Tabel 1. Aspek-aspek dalam Berpikir Kritis FRISCO

\begin{tabular}{|c|c|c|}
\hline No & $\begin{array}{c}\text { Kriteria Berpikir } \\
\text { Kritis }\end{array}$ & Indikator \\
\hline 1 & Focus (Fokus) & $\begin{array}{c}\text { Menngetahui poin utama sesuatu yang sedang dilakukan } \\
\text { atau dihadapi. Poin utama biasanya suatu kesimpulan. }\end{array}$ \\
\hline 2 & Reason (alasan) & $\begin{array}{c}\text { Memberikan alasan-alasan yang mendukung } \\
\text { kesimpulan/keputusan yang diambil }\end{array}$ \\
\hline 3 & $\begin{array}{c}\text { Inference } \\
\text { Kesimpulan) }\end{array}$ & $\begin{array}{c}\text { Proses penarikan kesimpulan yang masuk akal, yaitu } \\
\text { mengikuti langkah-langkah argumentasi yang logis menuju } \\
\text { kesimpulan/keputusan }\end{array}$ \\
\hline 4 & Situation (Situasi) & $\begin{array}{c}\text { Mengungkapkan faktor-faktor penting yang perlu } \\
\text { dipertimbangkan dalam membuat kesimpulan/keputusan }\end{array}$ \\
\hline 5 & $\begin{array}{c}\text { Clarity (Kejelasan) } \\
\text { Menjelaskan arti atau istilah-istilah yang berkaitan dengan } \\
\text { pembuatan kesimpulan/keputusan. }\end{array}$ \\
\hline 6 & $\begin{array}{c}\text { Overview (meninjau } \\
\text { kembali) }\end{array}$ & $\begin{array}{c}\text { Mengecek semua tindakan yang telah dilakukan apakah } \\
\text { masuk akal atau tidak. }\end{array}$ \\
\hline
\end{tabular}

Berbicara tentang macam-macam masalah matematika, Polya (1973) membagi masalah menjadi dua macam, yaitu 1) masalah menemukan (problem to find). Tujuan dari masalah menemukan adalah untuk menemukan objek khusus yang tidak diketahui. Hal yang tidak diketahui tersebut disebut quaesitum atau sesuatu yang dicari. Bagian-bagian utama dari masalah jenis ini adalah objek yang ditanyakan, data dan kondisi (syarat-syarat yang memenuhi soal). Ketiga hal tersebut harus dipahami dengan baik sebelum memulai memecahkan masalah. Biasanya masalah menemukan banyak diberikan pada pembelajaran matematika dasar. 2) Masalah membuktikan (problem to prove). Tujuan dari masalah membuktikan adalah untuk menentukan bahwa pernyataan khusus yang telah diberikan tersebut benar atau salah. Hal ini dapat dilakukan dengan membuktikan pernyataan tersebut atau pernyataan tersebut salah. Bagian-bagian dari masalah membuktikan adalah hipotesis dan kesimpulan.

Dalam penelitian ini masalah yang akan digunakan termasuk dalam masalah menemukan (problem to find) karena siswa dituntut untuk menemukan sesuatu yang belum diketahui dari sebuah masalah kontekstual (nyata) yang disajikan dalam bentuk cerita. Dalam pemecahan masalah harus dikaitkan dengan masalah-masalah kontekstual, agar siswa langsung berhadapan dengan masalah realistik. Suharta (2002) menyatakan bahwa agar pembelajaran menjadi bermakna (meaningful) maka dalam pembelajaran di kelas perlu mengaitkan pengalaman kehidupan nyata anak dengan bentukbentuk bangunan geometri yang ada disekitar lingkungan. Pada proses pembelajaran matematika realistik berbasis kontekstual, siswa menjadi fokus dari semua aktivitas dalam proses mengajar belajar di kelas. Hal ini menjadikan siswa aktif dalam kegiatan belajar mengajar (Suherman, 2004) Pengalaman belajar yang diperoleh siswa melalui kegiatan bertindak, mencari dan menemukan sendiri tidak akan mudah dilupakan.

Gaya belajar yang dimiliki setiap individu merupakan modal yang dapat digunakan pada saat belajar. Perbedaan gaya belajar tersebut juga dapat menyebabkan terjadinya perbedaan dalam 
Proses Berpikir Kritis Siswa dalam memecahkan Masalah Matematika Realistik Materi Geometri Ditinjau Dari Gaya Belajar Fisensius Yesekiel Naja ${ }^{1}$, Agustina $\mathrm{Mei}^{2}$, Sofia Sa'o ${ }^{3}$

Jupika: Jurnal Pendidikan Matematika, Volume 3. Nomor 2. September 2020. Hal.51-60

mengevaluasi terhadap proses berpikir dalam menyelesaikan masalah pada setiap individu. Menurut Gunawan (2006) gaya belajar adalah cara yang sangat kita sukai dalam melakukan kegiatan berpikir, memproses dan mengerti suatu informasi. Sedangkan menurut Hudojo (2001) Gaya belajar adalah kombinasi dari bagaimana seseorang menyerap, dan kemudian mengatur serta mengolah informasi. Dari pendapat di atas dapat disimpulkan bahwa belajar merupakan suatu proses dari individu untuk melakukan perubahan-perubahan dalam dirinya secara aktif yang dapat berupa perubahan tingkah laku yang lebih baik. Sedangkan gaya belajar adalah cara yang dipilih seseorang untuk mempermudah memproses informasi untuk melakukan perubahan yang lebih baik pada dirinya. Gaya belajar yang dimiliki setiap individu merupakan modal yang dapat digunakan pada saat mereka belajar.

\section{METODE}

Penelitian ini merupakan penelitian deskriptif dengan menggunakan pendekatan kualitatif. Untuk memperoleh data yang dibutuhkan dalam penelitian ini, dilakukan pengambilan data berupa tes pemecahan masalah (TPM) dan wawancara berkaitan dengan hasil pekerjaan siswa atas TPM yang telah diberikan. Data yang diperoleh berupa data hasil tes dan data hasil wawancara.

Subjek penelitian ini adalah siswa kelas VII SMP Negeri 2 Ende Selatan yang memiliki gaya belajar visual, auditori dan kinestetik yang dikenal dengan gaya belajar V-A-K. Proses pemilihan siswa yang memiliki gaya belajar V-A-K dengan menggunakan instrumen yang diadaptasi dari Chislett \& Chapman (2005) yang terdiri dari 30 pertanyaan dengan 3 pilihan jawaban.

Untuk memperoleh data yang diinginkan dalam penelitian ini, digunakan beberapa teknik pengumpulan data, yaitu: 1) Pemberian TPM. Pengumpulan data profil berpikir kritis dalam memecahkan masalah dilakukan dengan tes tertulis. 2) Wawancara. Wawancara dilakukan untuk memperoleh informasi lebih detail tentang berpikir kritis siswa dalam memecahkan masalah geometri.

Analisis data dilakukan sebagai berikut; 1) Analisis data hasil tugas pemecahan masalah yang dilakukan berdasarkan kebenaran pemecahan masalah yang dilakukan subjek penelitian. Jawaban subjek tersebut kemudian dianalisis sesuai dengan kriteria berpikir kritis FRISCO. 2) Analisis hasil wawancara yang selanjutnya dianalisis dengan langkah-langkah reduksi data, penyajian data, penarikan kesimpulan.

\section{HASIL DAN PEMBAHASAN}

Instrumen gaya belajar dalam penelitian ini digunakan untuk mengetahui gaya belajar siswa. Instrumen yang digunakan diadaptasi dari daftar pertanyaan gaya belajar yang dikembangkan oleh Chislett, V. \& Chapman (2005). Kegiatan pemilihan subjek penelitian dimulai dengan pemilihan kelas, berdasarkan informasi dari guru mata pelajaran matematika, tentang pendistribusian siswa yang kemampuan merata (kemampuan tinggi, sedang dan rendah) dengan jumlah siswa yang sama, maka 
Proses Berpikir Kritis Siswa dalam memecahkan Masalah Matematika Realistik Materi Geometri Ditinjau Dari Gaya Belajar Fisensius Yesekiel Naja ${ }^{1}$, Agustina $\mathrm{Mei}^{2}$, Sofia Sa'o ${ }^{3}$

Jupika: Jurnal Pendidikan Matematika, Volume 3. Nomor 2. September 2020. Hal.51-60

kelas yang dipilih adalah kelas VIIA yang berjumlah 22 siswa dan kelas VIIB berjumlah 22 siswa dan diberikan tes gaya belajar.

Dari hasil tes gaya belajar diperoleh 8 siswa bergaya belajar visual, 6 siswa bergaya belajar auditori dan 5 siswa bergaya belajar kinestetik. Siswa dikelompokkan berdasarkan gaya belajar masing-masing. Setelah tes gaya belajar, dan diperoleh siswa dengan gaya belajar berbeda tersebut, peneliti meminta pertimbangan dari guru matematika tentang kriteria yang harus dipenuhi yakni (a) tingkat kemampuan matematika yang sama (kemampuan tinggi) dan (b) kemampuan komunikasi calon subjek penelitian baik secara lisan maupun tertulis. Berdasarkan kriteria, terpilih 3 siswa terdiri dari 1 siswa visual dengan inisial ASM, 1 siswa auditori dengan inisial MJ dan 1 siswa kinestetik dengan inisial HM yang ditetapkan sebagai subjek penelitian.

Subjek visual, ketika memahami masalah, menyatakan bahwa masalah pada TPM I adalah luas daerah. Selanjutnya, subjek menjelaskan inferensinya bahwa terlebih dahulu harus mengetahui luas seluruh ruang dan luas daerah yang tidak dicat. Subjek mengetahui semua informasi yang disajikan dalam soal dan mengetahui apa yang ditanyakan dalam soal. Subjek juga dapat menjelaskan maksud ukuran dinding yaitu luas daerah. Subjek memeriksa kembali pemahamannya terhadap masalah yang dihadapi dengan menuliskan satu persatu dan membaca ulang kembali.

Subjek visual, ketika merencanakan mengerjakan masalah TPM I memilih cara langsung karena menurut dia cara langsung lebih cepat dan mudah, yaitu langsung menghitung luas daerah, selanjutnya mencari biaya yang harus dikeluarkan. Subjek juga mengetahui hal-hal yang akan dilakukan ketika menerapkan rencananya. Subjek memeriksa kembali hal-hal yang telah dilakukan dengan menuliskan satu persatu dan membaca kembali.

Subjek visual, ketika melaksanakan rencana, terlebih dahulu menghitung luas daerah yang akan dicat. Langkah tersebut dia lakukan karena berdasarkan apa yang sudah direncanakan sebelumnya. Subjek juga mengetahui langkah-langkah penyelesaiannya, awalnya subjek menghitung luas daerah yang akan dicat, selanjutnya membagi dengan luas daerah yang dapat dicat perkaleng cat, sehingga subjek dapat menghitung besarnya uang yang harus dikeluarkan. Subjek memeriksa kembali semua hal-hal yang telah dilakukan saat melaksanakan rencana.

Selanjutnya subjek memeriksa kembali hasil pekerjaannya agar bisa memperbaiki jika ada kekeliruan atau kesalahan pada jawabannya. Subjek mengetahui hal-hal penting yang harus diperiksa, yaitu memeriksa soal, jawaban dan alasan. Selanjutnya subjek mampu menjelaskan maksudnya memeriksa dengan memperhatikan angka-angkanya yaitu pada proses perhitungan. Subjek tidak memeriksa kembali hal-hal yang telah dilakukan dalam memeriksa jawabannya. Proses berpikir kritis subjek visual dapat dilihat pada tabel berikut ini: 
Tabel 2. Proses Berpikir Kritis Subjek Visual dalam Memecahkan Masalah

\begin{tabular}{|c|c|c|c|c|}
\hline $\begin{array}{c}\text { Kriteria } \\
\text { BK }\end{array}$ & $\begin{array}{c}\text { Memahami } \\
\text { Masalah }\end{array}$ & Membuat Rencana & $\begin{array}{c}\text { Melaksanakan } \\
\text { rencana }\end{array}$ & $\begin{array}{c}\text { Memeriksa } \\
\text { Kembali }\end{array}$ \\
\hline $\mathrm{F}$ & $\begin{array}{l}\text { Membangun } \\
\text { makna tentang } \\
\text { masalah yang } \\
\text { dihadapi. }\end{array}$ & $\begin{array}{l}\text { Menentukan cara } \\
\text { untuk memecahkan } \\
\text { masalah yang } \\
\text { dihadapi. }\end{array}$ & $\begin{array}{l}\text { Menjelaskan } \\
\text { langkah-langkah } \\
\text { penerapan cara } \\
\text { yang telah dipilih } \\
\text { sebelumnya. }\end{array}$ & $\begin{array}{l}\text { Memutuskan } \\
\text { untuk memeriksa } \\
\text { kembali hasil } \\
\text { pekerjaannya. }\end{array}$ \\
\hline $\mathrm{R}$ & $\begin{array}{l}\text { Memberikan } \\
\text { alasan yang logis } \\
\text { tentang rumusan } \\
\text { masalah yang telah } \\
\text { dibangun. }\end{array}$ & $\begin{array}{l}\text { Memberikan alasan } \\
\text { yang logis mengapa } \\
\text { ia memilih } \\
\text { menggunakan cara } \\
\text { tersebut. }\end{array}$ & $\begin{array}{l}\text { Mengetahui alasan } \\
\text { mengapa langkah } \\
\text { penerapannya } \\
\text { demikian. }\end{array}$ & $\begin{array}{l}\text { Memberikan } \\
\text { alasan yang logis } \\
\text { mengapa ia perlu } \\
\text { memeriksa } \\
\text { kembali hasil } \\
\text { pekerjaannya. }\end{array}$ \\
\hline I & $\begin{array}{l}\text { Menjelaskan } \\
\text { proses penarikan } \\
\text { kesimpulannya } \\
\text { tentang masalah } \\
\text { yang dibangun. }\end{array}$ & $\begin{array}{l}\text { Menjelaskan proses } \\
\text { penarikan } \\
\text { kesimpulan } \\
\text { menggunakan cara } \\
\text { yang telah dipilih. }\end{array}$ & $\begin{array}{l}\text { Menjelaskan proses } \\
\text { penarikan } \\
\text { kesimpulan untuk } \\
\text { melakukan } \\
\text { langkah-langkah } \\
\text { penerapan dengan } \\
\text { masuk akal. }\end{array}$ & $\begin{array}{l}\text { Menjelaskan } \\
\text { proses penarikan } \\
\text { kesimpulan untuk } \\
\text { memeriksa } \\
\text { pekerjaan dengan } \\
\text { masuk akal. }\end{array}$ \\
\hline $\mathrm{S}$ & $\begin{array}{l}\text { Mengetahui semua } \\
\text { hal yang diketahui } \\
\text { dan yang } \\
\text { ditanyakan dalam } \\
\text { soal. }\end{array}$ & $\begin{array}{l}\text { Mengetahui hal-hal } \\
\text { yang harus } \\
\text { dilakukan ketika } \\
\text { menggunakan cara } \\
\text { yang dipilih. }\end{array}$ & $\begin{array}{l}\text { Mengetahui dengan } \\
\text { jelas langkah- } \\
\text { lagkah } \\
\text { penerapannya. }\end{array}$ & $\begin{array}{l}\text { Mengetahui hal- } \\
\text { hal yang harus } \\
\text { diperhatikan } \\
\text { ketika subjek } \\
\text { memeriksa } \\
\text { kembali } \\
\text { pekerjaannya. } \\
\end{array}$ \\
\hline $\mathrm{C}$ & $\begin{array}{l}\text { Menjelaskan } \\
\text { istilah-istilah yang } \\
\text { digunakan saat } \\
\text { berpendapat } \\
\text { dengan jelas. }\end{array}$ & $\begin{array}{l}\text { Menjelaskan } \\
\text { tentang istilah yang } \\
\text { digunakan dalam } \\
\text { berpendapat dengan } \\
\text { jelas. }\end{array}$ & $\begin{array}{l}\text { Menjelaskan hal- } \\
\text { hal yang dikatakan } \\
\text { ketika berpendapat. }\end{array}$ & $\begin{array}{l}\text { Menjelaskan } \\
\text { istilah yang } \\
\text { digunakan ketika } \\
\text { berpendapat } \\
\text { dalam } \\
\text { menjelaskan } \\
\text { pemeriksaannya. }\end{array}$ \\
\hline $\mathrm{O}$ & $\begin{array}{l}\text { Memeriksa } \\
\text { kembali proses } \\
\text { pemahaman } \\
\text { terhadap masalah } \\
\text { yang dihadapi } \\
\text { dengan } \\
\text { menuliskan satu } \\
\text { persatu dan } \\
\text { membaca ulang } \\
\text { lagi. }\end{array}$ & $\begin{array}{l}\text { Memeriksa kembali } \\
\text { hal-hal yang telah } \\
\text { dilakukan dengan } \\
\text { menuliskan satu } \\
\text { persatu dan } \\
\text { membaca ulang } \\
\text { kembali. }\end{array}$ & $\begin{array}{l}\text { Memeriksa semua } \\
\text { hal-hal yang telah } \\
\text { dilakukan. }\end{array}$ & $\begin{array}{l}\text { Tidak memeriksa } \\
\text { kembali hal-hal } \\
\text { yang telah } \\
\text { dilakukannya. }\end{array}$ \\
\hline
\end{tabular}


Proses berpikir kritis subjek auditory dapat dilihat pada tabel berikut ini:

Tabel 3. Profil Berpikir Kritis Subjek Auditory dalam Memecahkan Masalah

\begin{tabular}{|c|c|c|c|c|}
\hline $\begin{array}{c}\text { Kriteria } \\
\text { BK }\end{array}$ & $\begin{array}{l}\text { Memahami } \\
\text { Masalah }\end{array}$ & Membuat Rencana & $\begin{array}{l}\text { Melaksanakan } \\
\text { rencana }\end{array}$ & $\begin{array}{l}\text { Memeriksa } \\
\text { Kembali }\end{array}$ \\
\hline $\mathbf{F}$ & $\begin{array}{l}\text { Membangun } \\
\text { makna tentang } \\
\text { masalah yang } \\
\text { dihadapi. }\end{array}$ & $\begin{array}{l}\text { Menentukan cara } \\
\text { untuk memecahkan } \\
\text { masalah yang } \\
\text { dihadapi. }\end{array}$ & $\begin{array}{l}\text { Menjelaskan } \\
\text { langkah-langkah } \\
\text { penerapan cara } \\
\text { yang telah dipilih } \\
\text { sebelumnya. }\end{array}$ & $\begin{array}{l}\text { Memeriksa kembali } \\
\text { hasil pekerjaannya. }\end{array}$ \\
\hline $\mathbf{R}$ & $\begin{array}{l}\text { Memberikan } \\
\text { alasan yang logis } \\
\text { tentang rumusan } \\
\text { masalah yang } \\
\text { telah dibangun. }\end{array}$ & $\begin{array}{l}\text { Memberikan alasan } \\
\text { yang logis mengapa } \\
\text { ia memilih } \\
\text { menggunakan cara } \\
\text { tersebut. }\end{array}$ & $\begin{array}{l}\text { Mengetahui } \\
\text { alasan mengapa } \\
\text { langkah } \\
\text { penerapannya } \\
\text { demikian. }\end{array}$ & $\begin{array}{l}\text { Memberikan alasan } \\
\text { yang logis mengapa } \\
\text { ia perlu memeriksa } \\
\text { kembali hasil } \\
\text { pekeriaannya. }\end{array}$ \\
\hline I & $\begin{array}{l}\text { Menjelaskan } \\
\text { proses penarikan } \\
\text { kesimpulannya } \\
\text { tentang masalah } \\
\text { yang dibangun } \\
\text { dengan masuk } \\
\text { akal. }\end{array}$ & $\begin{array}{l}\text { Menjelaskan proses } \\
\text { penarikan } \\
\text { kesimpulan } \\
\text { menggunakan cara } \\
\text { tersebut dengan } \\
\text { masuk akal. }\end{array}$ & $\begin{array}{l}\text { Menjelaskan } \\
\text { proses penarikan } \\
\text { kesimpulan untuk } \\
\text { melakukan } \\
\text { langkah-langkah } \\
\text { penerapan } \\
\text { tersebut dengan } \\
\text { masuk akal. }\end{array}$ & $\begin{array}{l}\text { Menjelaskan proses } \\
\text { penarikan } \\
\text { kesimpulan untuk } \\
\text { memeriksa } \\
\text { pekerjaan. }\end{array}$ \\
\hline $\mathbf{S}$ & $\begin{array}{l}\text { Mengetahui apa } \\
\text { diketahui dan } \\
\text { yang ditanyakan } \\
\text { dalam soal. }\end{array}$ & $\begin{array}{l}\text { Mengetahui hal-hal } \\
\text { yang dilakukan } \\
\text { ketika menggunakan } \\
\text { cara yang dipilih. }\end{array}$ & $\begin{array}{l}\text { Mengetahui } \\
\text { langkah-lagkah } \\
\text { penerapannya. }\end{array}$ & $\begin{array}{l}\text { Mengetahui hal-hal } \\
\text { apa saja yang harus } \\
\text { diperhatikan ketika } \\
\text { memeriksa kembali } \\
\text { pekerjaannya. }\end{array}$ \\
\hline $\mathbf{C}$ & $\begin{array}{l}\text { Menjelaskan } \\
\text { istilah-istilah } \\
\text { yang digunakan } \\
\text { saat berpendapat } \\
\text { dengan jelas. } \\
\end{array}$ & $\begin{array}{l}\text { Menjelaskan tentang } \\
\text { istilah yang } \\
\text { digunakan dalam } \\
\text { berpendapat dengan } \\
\text { jelas. }\end{array}$ & $\begin{array}{l}\text { Menjelaskan hal- } \\
\text { hal yang } \\
\text { dikatakan ketika } \\
\text { berpendapat. }\end{array}$ & $\begin{array}{l}\text { Menjelaskan istilah } \\
\text { yang digunakan } \\
\text { ketika berpendapat } \\
\text { dalam } \\
\text { pemeriksaannya. }\end{array}$ \\
\hline $\mathbf{O}$ & $\begin{array}{l}\text { Tidak memeriksa } \\
\text { kembali hal-hal } \\
\text { yang dilakukan } \\
\text { ketika memahami. }\end{array}$ & $\begin{array}{l}\text { Tidak memeriksa } \\
\text { kembali hal-hal yang } \\
\text { telah direncanakan. }\end{array}$ & $\begin{array}{l}\text { Memeriksa semua } \\
\text { hal-hal yang telah } \\
\text { dilakukan, dengan } \\
\text { cara melihat dan } \\
\text { membaca } \\
\text { semuanya.. }\end{array}$ & $\begin{array}{l}\text { Tidak memeriksa } \\
\text { kembali hal-hal } \\
\text { yang dilakukannya. }\end{array}$ \\
\hline
\end{tabular}

Subjek auditori ketika memahami masalah menyatakan bahwa masalah pada TPM I adalah biaya yang dikeluarkan untuk membeli cat. Selanjutnya subjek menjelaskan inferensinya bahwa terlebih dahulu harus menghitung ukuran ruang dan ukuran daerah yang tidak dicat. subjek mengetahui semua informasi yang disajikan dalam soal dan mengetahui apa yang ditanyakan dalam soal. Subjek dapat menjelaskan maksud ukuran ruang yaitu luas daerah. Subjek tidak memeriksa kembali pemahamannya.

Subjek auditori merencanakan mengerjakan masalah TPM I yaitu langsung menghitung ukuran ruang, ukuran pintu, ukuran jendela dan ukuran ventilasi selanjutnya mencari biaya yang harus dikeluarkan. Subjek menjelaskan inferensinya bahwa dengan menggunakan cara tersebut lebih simpel 
Proses Berpikir Kritis Siswa dalam memecahkan Masalah Matematika Realistik Materi Geometri Ditinjau Dari Gaya Belajar Fisensius Yesekiel Naja ${ }^{1}$, Agustina $\mathrm{Mei}^{2}$, Sofia Sa'o ${ }^{3}$

Jupika: Jurnal Pendidikan Matematika, Volume 3. Nomor 2. September 2020. Hal.51-60

dan cepat tapi tetap detail. Subjek mengetahui hal-hal yang akan dilakukan ketika menerapkan rencananya. Subjek tidak memeriksa kembali hal-hal yang telah dilakukan ketika membuat rencana.

Subjek auditori dalam melaksanakan rencana terlebih dahulu menghitung ukuran ruang. Langkah tersebut dilakukan karena berdasarkan apa yang sudah direncanakan sebelumnya. Subjek juga mengetahui langkah-langkah penyelesaiannya, awalnya subjek menghitung luas daerah, selanjutnya membagi dengan luas daerah yang dapat dicat perkaleng cat, sehingga subjek dapat menghitung besarnya biaya yang harus dikeluarkan. Subjek memeriksa kembali semua hal-hal yang telah dilakukan dengan cara melihat dan membaca lagi.

Selanjutnya subjek memeriksa kembali hasil pekerjaannya agar bisa memperbaiki jika ada kekeliruan atau kesalahan pada jawabannya. Subjek mengetahui hal-hal penting yang diperiksa, yaitu memeriksa apa yang diketahui, yang ditanyakan dan hasilnya. Selanjutnya subjek mampu menjelaskan maksudnya memeriksa dengan memperhatikan angka-angka dan proses perhitungan. Subjek tidak memeriksa kembali hal-hal yang telah dilakukan dalam memeriksa jawabannya.

Subjek kinestetik dalam memahami masalah, menyatakan bahwa masalah dalam TPM I adalah jumlah uang yang dikeluarkan untuk membeli cat. Subjek merumuskan masalah tersebut karena pada kalimat yang terdapat pada soal. Ketika diminta untuk menjelaskan proses inferensinya, subjek menyatakan luas ruang dibagi dengan luas daerah yang dapat dicat perkaleng cat. Subjek mengetahui seluruh informasi yang ada dalam soal. Subjek juga menjelaskan maksud dari ukuran ruang yang ia sebutkan adalah ukuran lantainya. Selanjutnya subjek tidak memeriksa kembali hal-hal yang dilakukan pada saat memahami masalah.

Subjek merencanakan penyelesaian dengan menggambarkan sketsa ruang kepala sekolah. Subjek merencanakan untuk menghitung luas pintu, luas jendela dan luas ventilasi, kemudian menghitung satu-satu sisi dinding sesuai dengan yang telah digambarkan. Selanjutnya subjek menjelaskan proses inferensinya menurut subjek akan lebih cepat mengerjakannya jika terlebih dahulu menghitung luas pintu, jendela dan ventilasi. Subjek mengakui bahwa ia baru mengetahui setiap hal yang ia harus hitung ketika ia membaca soal dan langsung menghitungnya. Subjek menjelaskan tentang persegipanjang adalah memiliki panjang dan lebar. Sedangkan luas persegipanjang adalah daerah yang dibatasi oleh panjang dan lebar. Subjek menyatakan bahwa ia tidak memeriksa kembali apa yang telah direncanakan.

Subjek kinestetik menjelaskan langkah-langkah penyelesaiannya yaitu setelah diperoleh luas dinding, selanjutnya dibagi dengan luas daerah yang dapat dicat perkaleng cat. Selanjutnya ketika ditanya tentang rumus luas persegipanjang subjek mengatakan panjang kali lebar. Subjek mengatakan setelah mengerjakan ia memeriksa kembali dengan memperhatikan angka-angka dan hasil akhirnya.

Subjek kinestetik menyatakan bahwa ia memeriksa kembali hasil pekerjaannya. Subjek memutuskan untuk memeriksa ukuran-ukuran pintu, jendela dan ventilasi, maksudnya panjang sisi- 
Proses Berpikir Kritis Siswa dalam memecahkan Masalah Matematika Realistik Materi Geometri Ditinjau Dari Gaya Belajar Fisensius Yesekiel Naja ${ }^{1}$, Agustina $\mathrm{Mei}^{2}$, Sofia $\mathrm{Sa}^{\prime}{ }^{3}$

Jupika: Jurnal Pendidikan Matematika, Volume 3. Nomor 2. September 2020. Hal.51-60

sisi sudah sama dengan yang diketahui. Subjek mengungkapkan inferensinya bahwa dengan memeriksa angka-angka tersebut agar perhitungannya tepat sehingga hasilnya tidak diragukan lagi.

Proses berpikir kritis subjek kinestetik dapat dilihat pada tabel berikut ini:

Tabel 4. Profil Berpikir Kritis Subjek Kinestetik dalam Memecahkan Masalah

\begin{tabular}{|c|c|c|c|c|}
\hline $\begin{array}{c}\text { Kriteria } \\
\text { BK }\end{array}$ & $\begin{array}{l}\text { Memahami } \\
\text { Masalah }\end{array}$ & Membuat Rencana & $\begin{array}{c}\text { Melaksanakan } \\
\text { rencana }\end{array}$ & $\begin{array}{c}\text { Memeriksa } \\
\text { Kembali }\end{array}$ \\
\hline $\mathbf{F}$ & $\begin{array}{l}\text { Membangun } \\
\text { makna tentang } \\
\text { masalah yang } \\
\text { dihadapi, }\end{array}$ & $\begin{array}{l}\text { Menentukan cara } \\
\text { untuk memecahkan } \\
\text { masalah yang } \\
\text { dihadapi. }\end{array}$ & $\begin{array}{l}\text { Menjelaskan } \\
\text { langkah-langkah } \\
\text { penerapan cara } \\
\text { yang telah dipilih } \\
\text { sebelumnya. }\end{array}$ & $\begin{array}{l}\text { Memeriksa kembali } \\
\text { hasil pekerjaannya. }\end{array}$ \\
\hline $\mathbf{R}$ & $\begin{array}{l}\text { Memberikan } \\
\text { alasan yang logis } \\
\text { tentang rumusan } \\
\text { masalah yang } \\
\text { telah dibangun. }\end{array}$ & $\begin{array}{l}\text { Memberikan alasan } \\
\text { yang logis mengapa } \\
\text { ia memilih } \\
\text { menggunakan cara } \\
\text { tersebut. }\end{array}$ & $\begin{array}{l}\text { Menegetahui alasan } \\
\text { mengapa langkah } \\
\text { penerapannya } \\
\text { demikian. }\end{array}$ & $\begin{array}{l}\text { Memberikan alasan } \\
\text { yang logis mengapa } \\
\text { subjek memeriksa } \\
\text { kembali hasil } \\
\text { pekerjaannya. }\end{array}$ \\
\hline I & $\begin{array}{l}\text { Menjelaskan } \\
\text { proses penarikan } \\
\text { kesimpulannya } \\
\text { tentang masalah } \\
\text { yang dibangun } \\
\text { dengan masuk } \\
\text { akal. }\end{array}$ & $\begin{array}{l}\text { Menjelaskan proses } \\
\text { penarikan } \\
\text { keputusannya dengan } \\
\text { masuk akal. }\end{array}$ & $\begin{array}{l}\text { Tidak dapat } \\
\text { menjelaskan proses } \\
\text { penarikan } \\
\text { keputusan untuk } \\
\text { melakukan } \\
\text { langkah-langkah } \\
\text { penerapan, karena } \\
\text { subjek menganggap } \\
\text { rencana yang telah } \\
\text { dipikirkan } \\
\text { sebelumnya itu } \\
\text { bukanlah sebuah } \\
\text { rencana yang jelas. }\end{array}$ & $\begin{array}{l}\text { Menjelaskan proses } \\
\text { penarikan } \\
\text { keputusan untuk } \\
\text { memeriksa } \\
\text { pekerjaannya } \\
\text { dengan masuk akal. }\end{array}$ \\
\hline$S$ & $\begin{array}{l}\text { Mengetahui } \\
\text { semua hal yang } \\
\text { diketahui dan } \\
\text { yang ditanyakan } \\
\text { dalam soal. }\end{array}$ & $\begin{array}{l}\text { Belum mengetahui } \\
\text { semua hal yang harus } \\
\text { dilakukan ketika } \\
\text { melaksanakan cara } \\
\text { yang dipilih. }\end{array}$ & $\begin{array}{l}\text { Mengetahui } \\
\text { langkah-langkah } \\
\text { penerapannya. }\end{array}$ & $\begin{array}{l}\text { Mengetahui hal-hal } \\
\text { yang harus } \\
\text { diperhatikan ketika } \\
\text { subjek memeriksa } \\
\text { kembali hasil } \\
\text { pekerjaannya. }\end{array}$ \\
\hline $\mathbf{C}$ & $\begin{array}{l}\text { Menjelaskan } \\
\text { istilah yang } \\
\text { digunakan saat } \\
\text { berpendapat. }\end{array}$ & $\begin{array}{l}\text { Menjelaskan istilah } \\
\text { yang digunakan } \\
\text { dalam berpendapat. }\end{array}$ & $\begin{array}{l}\text { Menjelaskan hal- } \\
\text { hal penting yang } \\
\text { ketika berpendapat. }\end{array}$ & $\begin{array}{l}\text { Menjelaskan istilah } \\
\text { yang digunakan } \\
\text { ketika berpendapat } \\
\text { dalam } \\
\text { pemeriksaannya. }\end{array}$ \\
\hline $\mathbf{O}$ & $\begin{array}{l}\text { Tidak memeriksa } \\
\text { kembali hal-hal } \\
\text { yang telah } \\
\text { dilakukan dalam } \\
\text { memahami } \\
\text { masalah. }\end{array}$ & $\begin{array}{l}\text { Tidak memeriksa } \\
\text { kembali hal-hal yang } \\
\text { telah dilakukan } \\
\text { dalam membuat } \\
\text { rencana. }\end{array}$ & $\begin{array}{l}\text { Memeriksa kembali } \\
\text { semua yang telah } \\
\text { dilakukan dengan } \\
\text { cara } \\
\text { memperhatikan } \\
\text { kembali sketsa } \\
\text { gambar dan } \\
\text { mencocokan } \\
\text { dengan hasil } \\
\text { pekerjaannya. }\end{array}$ & $\begin{array}{l}\text { Tidak memeriksa } \\
\text { kembali hal-hal } \\
\text { yang telah } \\
\text { dilakukan ketika } \\
\text { memeriksa } \\
\text { pekerjaannya. }\end{array}$ \\
\hline
\end{tabular}


Proses Berpikir Kritis Siswa dalam memecahkan Masalah Matematika Realistik Materi Geometri Ditinjau Dari Gaya Belajar Fisensius Yesekiel Naja ${ }^{1}$, Agustina $\mathrm{Mei}^{2}$, Sofia $\mathrm{Sa}^{\prime}{ }^{3}$

Jupika: Jurnal Pendidikan Matematika, Volume 3. Nomor 2. September 2020. Hal.51-60

\section{KESIMPULAN}

Berdasarkan analisis data, maka dapat disimpulkan bahwa subjek yang memiliki gaya belajar visual, proses berpikir kritisnya dalam memecahkan masalah matematika realistik, mampu memahami masalah, subjek belum mampu menentukan cara untuk memecahkan masalah, subjek belum mampu melaksanakan penuelesaian dan subjek tidak memeriksa kembali.

Subjek yang memiliki gaya belajar auditori, profil berpikir kritisnya dalam memecahkan masalah matematika realistik mampu memahami masalah, mampu melaksanakan dengan baik, namun subjek tidak memeriksa kembali. Subjek yang memiliki gaya belajar kinestetik proses berpikir kritisnya dalam memecahkan masalah matematika realistik, mampu memahami masalah, mampu merencanakan masalah,subjek dapat melaksanakan dengan baik serta memeriksa kembali.

\section{DAFTAR PUSTAKA}

Chislett, V. \& Chapman, A. (2005). VAK Learning Styels Self-Assessment Questionnaire.

Ennis, R. H. (1995). Critical Thinking. New Jersey: Pretince-Hall.

Gokhale, A. . (2015). Collaborative Learning Enhance Critical Thinking. Jornal of Techonology Education.

Gunawan, A. W. (2006). Genius Learning Strategy. Jakarta: PT Gramedia Pustaka Utama.

Hudojo, H. (2001). Psikologi Kognitif untuk Pengembangan Kurikulum dan Pembelajaran Matematika. Departemen Pendidikan dan Kebudayaan, Jakarta.

Johnson, E. B. (2007). Contextual Teaching and Learning Menjadikan Kegiatan Belajar-Mengajar mengasyikan dan Bermakna (Ibnu Setiawan (ed.)

Polya, G. (1973). How To Solve It. Pricenton University Press. Princenton, New Jersey.

Sabandar, J. (2008). Thinking Classroom dalam Pembelajaran Matematika di Sekolah.

Siswono, T. Y. E. (2008). Model Pembelajaran Matematika Berbasis Pengajuan dan Pemecahan Masalah Untuk Meningkatkan Kemampuan Berpikir Kreatif. Unesa University Press.

Solso, R. L. (2008). Psikologi Kognitif. Jakarta: Erlangga.

Suharta, I. G. P. (2002). Matematika Realistik: Apa dan Bagimana. Jurnal Pendidikan Dan Kebudayaan, No.03 Depdiknas Jakarta, 03.

Suherman, E. (2004). Evaluasi Proses dan Hasil Belajar Siswa Matematika. Depdikbud. 